\title{
Maternal Hypothyroidism and Reproduction
}

\author{
Ahmed R.G* \\ Division of Anatomy and Embryology, Zoology Department, Faculty of Science, Beni-Suef University, Beni- \\ Suef, Egypt
}

*Corresponding Author: Ahmed R.G, Division of Anatomy and Embryology, Zoology Department, Faculty of Science, Beni-Suef University, Beni-Suef, Egypt.Email: ahmedragab08@gmail.com

\section{HYPOTHESIS}

The balance between the thyroid hormones (THs), thyroid-stimulating hormone (TSH), growth hormone $(\mathrm{GH})$ and insulin growth factors (IGFs) is crucial for the in utero and postnatal periods (Ahmed, 2011, 2012a,b, 2013, 2014, 2015a-c, 2016a-d, 2017a-v\& 2018a-j; Ahmed et al., 2010, 2013a,b, 2014, 2015a,b \&2018a,b; Ahmed and Incerpi, 2013; Van Hercket al., 2013; Ahmed and El-Gareib, 2014,Incerpi et al., 2014; Candelotti et al., 2015; De Vito et al., 2015; ElGhareeb et al., 2016; Ahmed and El-Gareib, 2017).On the other hand, early clarifications have pronouncedthe association between the thyroid dysfunctionand disorders in the reproduction process and sexual activity (Doufas and Mastorakos, 2000; Krassas and Perros, 2003;Wajner et al., 2009; Rijntjes et al., 2017).Hypothyroidism can alter the male fertility as the following (Donnelly and White, 2000; Carani et al., 2005; Krassas et al., 2008 \& 2010): (1) decrease the concentration of total testosterone; (2) diminish the concentration of free testosterone about 60\%; (3) reduce the libido; (4) erectile dysfunction; (5) increase the risk of testicular atrophy (Wortsman et al., 1987); and (6) defect the spermatogenesis. These results can be due to thyroid disorders induced the egress of free radicals (Iwasaki and Gagnon, 1992; Aitken and Krausz, 2001; Agarwal and Saleh, 2002; Mancini et al., 2009). Other data were reported by Gallagher (1966), Longcope et al. (1990), Krassas (2000), and Redmond (2004) who demonstrated that hypothyroidism can alter the female fertility as the following: (1) change the metabolism of peripheral estrogen; (2) alter the secretion of gonadotropin-releasing hormone $(\mathrm{GnRH})$ producing some abnormalities in the release of pulsatile luteinizing hormone (LH); (3) hyperprolactinemia; (4) decrease the concentration of total testosterone and estradiol; (5) reduce the metabolism of androgen; (6) augment the excretion of 2-oxygenated estrogens; and (7) luteal phase defect (Daya et al., 1988). In general, the hypoactive state of THs may cause infertility, and maternal complications (Davis et al., 1988; Stray-Pedersen \& StrayPedersen, 1984; Wajner et al., 2009; Rijntjes et al., 2017). More interestingly, the deterioration of thyroid disorders on the luteal phase can be attributed to the egress of free radicals and oxidative stress (Ahmed et al., 2008). These data are observed in human, animals and in vitro models. The oxidative stress can reduce the female fertility. In addition, a reduction in the antioxidant system has been assumed in infertility, and polycystic ovary (Ruder et al., 2008).

In the light of the previous thoughts, my data assume several visions. The balance in the maternal HPTA shows a noteworthy role in the reproduction process. In addition, the maternal thyroid dysfunctions (hypothyroidism) may deteriorate the sperm motility, luteal phase deficiency, reproduction process and sexual activity. The prolonged harmful effects of thyroid abnormalities can increase the egress of free radicals and cause male and female infertility. Thus, the management of the thyroid markers before the marriage and the gestation should be crucial for the endocrine, metabolic, and sexual improvement. This can improve the fertility of both male and female. However, additional studies are needed to discover whether the abnormalities in the maternal HPTA/thyroid gland during pregnancy may cause persistent disturbances in the reproduction process and sexual activity. The urologists and endocrinologists are essential to working together to avoid these unusual disorders. The issue remains open. 


\section{REFERENCES}

[1] Agarwal, A., Saleh, R.A., 2002. Role of antioxidants in male infertility: rationale, significance and treatment. Urology Clinics of North America, 29, 817-827.

[2] Ahmed, O.M., Abd El-Tawab, S.M., Ahmed, R.G., 2010. Effects of experimentally induced maternal hypothyroidism and hyperthyroidism on the development of rat offspring: I- The development of the thyroid hormonesneurotransmitters and adenosinergic system interactions. Int. J. Dev. Neurosci. 28, 437-454.

[3] Ahmed, O.M., Abd El-Tawab, S.M., Ahmed, R.G., 2010. Effects of experimentally induced maternal hypothyroidism and hyperthyroidism on the development of rat offspring: I- The development of the thyroid hormonesneurotransmitters and adenosinergic system interactions.Int. J. Dev. Neurosci. 28, 437-454.

[4] Ahmed, O.M., Ahmed, R.G., 2012. Hypothyroidism. In A New Look At Hypothyroidism. Dr. D. Springer (Ed.), ISBN: 978-953-51-0020-1), In Tech Open Access Publisher, Chapter 1, pp. 1-20.

[5] Ahmed, O.M., Ahmed, R.G., El-Gareib, A.W., El-Bakry, A.M., Abd El-Tawaba, S.M., 2012. Effects of experimentally induced maternal hypothyroidism and hyperthyroidism on the development of rat offspring: II-The developmental pattern of neurons in relation to oxidative stress and antioxidant defense system. Int. J. Dev. Neurosci. 30, 517-537.

[6] Ahmed, O.M., El-Gareib, A.W., El-bakry, A.M., Abd El-Tawab, S.M., Ahmed, R.G., 2008. Thyroid hormones states and brain development interactions. Int. J. Dev. Neurosci. 26(2), 147209. Review.

[7] Ahmed, R.G., 2011. Perinatal 2, 3, 7, 8tetrachlorodibenzo-p-dioxin exposure alters developmental neuroendocrine system. Food Chem. Toxicology, 49, 1276-1284.

[8] Ahmed, R.G., 2012a. Maternal-newborn thyroid dysfunction. In the Developmental Neuroendocrinology, pp. 1-369. Ed R.G. Ahmed. Germany: LAP LAMBERT Academic Publishing GmbH \& Co KG.

[9] Ahmed, R.G., 2012b. Maternal-fetal thyroid interactions, Thyroid Hormone, Dr. N.K. Agrawal (Ed.), ISBN: 978-953-51-0678-4, In Tech Open Access Publisher, Chapter 5, pp. 125-156.

[10] Ahmed, R.G., 2013. Early weaning PCB 95 exposure alters the neonatal endocrine system: thyroid adipokine dysfunction. J. Endocrinol. 219 (3), 205-215.

[11] Ahmed, R.G., 2014. Editorial: Do PCBs modify the thyroid-adipokine axis during development? Annals Thyroid Res. 1(1), 11-12.

ARC Journal of Animal and Veterinary Sciences
[12] Ahmed, R.G., 2015a. Chapter 1: Hypothyroidism and brain development. In advances in hypothyroidism treatment. Avid Science Borsigstr.9, 10115 Berlin, Berlin, Germany. Avid Science Publications level 6, Melange Towers, Wing a, Hitec City, Hyderabad, Telangana, India. pp. 1-40.

[13] Ahmed, R.G., 2015b. Hypothyroidism and brain developmental players. Thyroid Research J. 8(2), 1-12.

[14] Ahmed, R.G., 2015c. Editorials and Commentary: Maternofetal thyroid action and brain development. J. of Advances in Biology; 7(1), 1207-1213.

[15] Ahmed, R.G., 2016a. Gestational dexamethasone alters fetal neuroendocrine axis. Toxicology Letters, 258, 46-54.

[16] Ahmed, R.G., 2016b. Neonatal polychlorinated biphenyls-induced endocrine dysfunction. Ann. Thyroid. Res. 2 (1), 34-35.

[17] Ahmed, R.G., 2016c. Maternal iodine deficiency and brain disorders. Endocrinol. Metab.Syndr.5, 223.http://dx.doi.org/10.4172/2161-1017.1000 223.

[18] Ahmed, R.G., 2016d. Maternal bisphenol A alters fetal endocrine system: Thyroid adipokine dysfunction. Food Chem. Toxicology, 95, 168174.

[19] Ahmed, R.G.,2017a. Developmental thyroid diseases and GABAergic dysfunction. EC Neurology 8.1, 02-04.

[20] Ahmed, R.G., 2017b. Hyperthyroidism and developmental dysfunction. Arch Med. 9, 4.

[21] Ahmed, R.G.,2017c. Anti-thyroid drugs may be at higher risk for perinatal thyroid disease. EC Pharmacology and Toxicology 4.4, 140-142.

[22] Ahmed, R.G.,2017d. Perinatal hypothyroidism and cytoskeleton dysfunction. Endocrinol MetabSyndr 6, 271.doi:10.4172/2161-1017. 1000271

[23] Ahmed, R.G.,2017e. Developmental thyroid diseases and monoaminergic dysfunction. Advances in Applied Science Research 8(3), 0110.

[24] Ahmed, R.G.,2017f. Hypothyroidism and brain development.J. Anim Res Nutr.2(2), 13.

[25] Ahmed, R.G.,2017g. Antiepileptic drugs and developmental neuroendocrine dysfunction: Every why has A Wherefore.Arch Med 9(6), 2.

[26] Ahmed, R.G.,2017h. Gestational prooxidantantioxidant imbalance may be at higher risk for postpartum thyroid disease. Endocrinol Metab Syndr 6, 279. doi:10.4172/2161-1017.1000279.

[27] Ahmed, R.G.,2017i. Synergistic actions of thyroid-adipokines axis during development. Endocrinol Metab Syndr 6, 280.doi: 10.4172/ 2161-1017.1000280.

[28] Ahmed, R.G.,2017j. Thyroid-insulin dysfunction during development. International 
Journal of Research Studies in Zoology 3(4), 7375.DOI:http://dx.doi.org/10.20431/2454-941X. 0304010.

[29] Ahmed, R.G.,2017k. Developmental thyroid diseases and cholinergic imbalance. International Journal of Research Studies in Zoology 3(4), 70-72. DOI: http://dx.doi.org/ 10.20431/2454-941X.0304009.

[30] Ahmed, R.G.,20171. Thyroid diseases and developmental adenosinergic imbalance. Int $\mathbf{J}$ ClinEndocrinol 1(2), 053-055.

[31] Ahmed, R.G.,2017m. Maternal anticancer drugs and fetal neuroendocrine dysfunction in experimental animals. EndocrinolMetabSyndr 6, 281.doi:10.4172/2161-1017.1000281.

[32] Ahmed, R.G.,2017n. Letter: Gestational dexamethasone may be at higher risk for thyroid disease developing peripartum. Open Journal of Biomedical \& Life Sciences (Ojbili) 3(2), 01-06.

[33] Ahmed, R.G.,2017o. Deiodinases and developmental hypothyroidism. EC Nutrition 11.5, 183-185.

[34] Ahmed, R.G.,2017p. Maternofetal thyroid hormones and risk of diabetes. Int. J. of Res. Studies in Medical and Health Sciences 2(10), 18-21.

[35] Ahmed, R.G.,2017r. Association between hypothyroidism and renal dysfunctions. International Journal of Research Studies in Medical and Health Sciences 2(11), 1-4.

[36] Ahmed, R.G.,2017s. Maternal hypothyroidism and lung dysfunction. International Journal of Research Studies in Medical and Health Sciences 2(11), 8-11.

[37] Ahmed, R.G.,2017t. Endocrine disruptors; possible mechanisms for inducing developmental disorders. International journal of basic science in medicine (IJBSM)2(4), 157160.

[38] Ahmed, R.G.,2017u. Maternal thyroid hormones trajectories and neonatal behavioral disorders. ARC Journal of Diabetes and Endocrinology 3(2), 18-21.

[39] Ahmed, R.G.,2017v. Maternal thyroid dysfunction and neonatal cardiac disorders. Insights Biol Med. 1, 092-096.

[40] Ahmed, R.G.,2018a. Maternal hypothyroidism and neonatal testicular dysfunction. International Journal of Research Studies in Medical and Health Sciences 3(1), 8-12.

[41] Ahmed, R.G.,2018b. Maternal hypothyroidism and neonatal depression: Current perspective. International Journal of Research Studies in Zoology 4(1), 6-10. DOI: http://dx.doi.org/ 10.20431/2454-941X.0401002.

[42] Ahmed, R.G.,2018c. Non-genomic actions of thyroid hormones during development. App ClinPharmacolToxicol: ACPT-108. DOI: 10.29011/ACPT-109. 100008.

ARC Journal of Animal and Veterinary Sciences
[43] Ahmed, R.G.,2018d. Maternal thyroid function and placental hemodynamics. ARC Journal of Animal and Veterinary Sciences 4(1), 9-13. DOI: http://dx.doi.org/10.20431/2455-2518. 0401002.

[44] Ahmed, R.G.,2018e. Interactions between thyroid and growth factors during development. ARC Journal of Diabetes and Endocrinology 4(1), 1-4. DOI: http://dx.doi.org/ 10.20431/ 2455-5983.0401001.

[45] Ahmed, R.G.,2018f. Maternal thyroid hormones and neonatal appetite. ARC Journal of Nutrition and Growth 4(1), 18-22. DOI: http://dx.doi.org/10.20431/2455-2550.0401005.

[46] Ahmed, R.G.,2018g. Genomic actions of thyroid hormones during development. ARC Journal of Diabetes and Endocrinology 4(1), 5-8. DOI: http://dx.doi.org/10.20431/2455-5983.0401002.

[47] Ahmed, R.G.,2018h. Dysfunction of maternal thyroid hormones and psychiatric symptoms. American Research Journal of Endocrinology. 2(1), 1-6.

[48] Ahmed, R.G.,2018i. Is there a connection between maternal hypothyroidism and developing autism spectrum disorders? ARC Journal of Neuroscience 3(1), 5-8. DOI: http://dx.doi.org/10.20431/2456-057X.0301002

[49] Ahmed, R.G.,2018j.Maternal thyroid dysfunctions and neonatal bone mal development.American Research Journal of Endocrinology (in press) $\mathrm{xx}-\mathrm{xxx}$.

[50] Ahmed, R.G., Abdel-Latif, M., Ahmed F., 2015a.Protective effects of GM-CSF in experimental neonatal hypothyroidism. International Immunopharmacology 29, 538543.

[51] Ahmed, R.G., Abdel-Latif, M., Mahdi, E., ElNesr, K., 2015b. Immune stimulation improves endocrine and neural fetal outcomes in a model of maternofetal thyrotoxicosis. Int. Immunopharmacol. 29, 714-721.

[52] Ahmed, R.G., Davis, P.J., Davis, F.B., De Vito, P., Farias, R.N., Luly, P., Pedersen, J.Z., Incerpi, S., 2013a. Nongenomic actions of thyroid hormones: from basic research to clinical applications. An update. Immunology, Endocrine \& Metabolic Agents in Medicinal Chemistry, 13(1), 46-59.

[53] Ahmed, R.G., El-Gareib, A.W. 2014.Lactating PTU exposure: I- Alters thyroid-neural axis in neonatal cerebellum. Eur. J. of Biol. and Medical Sci. Res. 2(1), 1-16.

[54] Ahmed, R.G., El-Gareib, A.W., 2017.Maternal carbamazepine alters fetal neuroendocrinecytokines axis. Toxicology 382, 59-66.

[55] Ahmed, R.G., El-Gareib, A.W., Incerpi, S., 2014. Lactating PTU exposure: II- Alters thyroid-axis and prooxidant-antioxidant balance in neonatal cerebellum. Int. Res. J. of Natural Sciences 2(1), 1-20. 
[56] Ahmed, R.G., El-Gareib, A.W., Shaker, H.M., 2018a.Gestational 3,3',4,4',5-penta chloro biphenyl (PCB 126) exposure disrupts fetoplacental unit: Fetal thyroid-cytokines dysfunction. Life Sciences 192, 213-220.

[57] Ahmed, R.G., Incerpi, S., 2013. Gestational doxorubicin alters fetal thyroid-brain axis. Int. J. Devl. Neuroscience 31, 96-104.

[58] Ahmed, R.G., Incerpi, S., Ahmed, F., Gaber, A., 2013b. The developmental and physiological interactions between free radicals and antioxidant: Effect of environmental pollutants. J. of Natural Sci. Res. 3(13), 74-110.

[59] Ahmed, R.G., Walaa G.H., Asmaa F.S., 2018b.Suppressive effects of neonatal bisphenol A on the neuroendocrine system. Toxicology and Industrial Health Journal (in press).

[60] Aitken, R.J., Krausz, C., 2001. Oxidative stress, DNA damage and the $\mathrm{Y}$ chromosome. Reproduction, 122, 497-506.

[61] Candelotti, E., De Vito, P., Ahmed, R.G., Luly, P., Davis, P.J., Pedersen, J.Z., Lin, H-Y., Incerpi, I., 2015. Thyroid hormones crosstalk with growth factors: Old facts and new hypotheses. Immun., Endoc. \& Metab. Agents in Med. Chem., 15, 71-85.

[62] Carani, C., Isidori, A.M., Granata, A., Carosa, E., Maggi M., Lenzi, A., Tannini, E.A., 2005.Multicenter study on the prevalence of sexual symptoms in male hypo- and hyperthyroid patients. Journal of Clinical Endocrinology \& Metabolism, 90, 6472-6479.

[63] Davis, L.E., Leveno, K.J., Cunningham, F.G., 1988. Hypothyroidism complicating pregnancy. Obstetrics \& Gyencology, 72 (1), 108-112.

[64] Daya, S., Ward, S., Burrows, E., 1988. Progesterone profiles in luteal phase defect cycles and outcome of progesterone treatment in patients with recurrent spontaneous abortion. American Journal of Obstetrics \& Gynecology, 158 (2), 225-232.

[65] De Vito, P., Candelotti, E., Ahmed, R.G., Luly, P., Davis, P.J., Incerpi, S., Pedersen, J.Z., 2015.Role of thyroid hormones in insulin resistance and diabetes. Immun., Endoc. \& Metab. Agents in Med. Chem., 15, 86-93.

[66] Donnelly, P., White, C., 2000. Testicular dysfunction in men with primary hypothyroidism; reversal of hypogonadotrophic hypogonadism with replacement thyroxine. Clinical Endocrinology (Oxford), 52, 197-201.

[67] Doufas, A.G., Mastorakos, G., 2000. The hypothalamic-pituitary-thyroid axis and the female reproductive system. Annals of the New York Academy of Science, 900, 65-76.

[68] El-bakry, A.M., El-Ghareeb, A.W., Ahmed, R.G., 2010.Comparative study of the effects of experimentally-induced hypothyroidism and hyperthyroidism in some brain regions in albino rats.Int. J. Dev. Neurosci. 28, 371-389.

ARC Journal of Animal and Veterinary Sciences
[69] El-Ghareeb, A.A., El-Bakry, A.M., Ahmed, R.G., Gaber, A., 2016.Effects of zinc supplementation in neonatal hypothyroidism and cerebellar distortion induced by maternal carbimazole. Asian Journal of Applied Sciences 4(04), 1030-1040.

[70] Gallagher, T.F., Fukushima, D.K., Noguchi, S., Fishman, J., Bradlow, H.L., Cassouto, J., Zumoff, B., Hellman, L., 1966. Recent studies in steroid hormone metabolism in man. Recent Progress in Hormone Research, 22, 283-302.

[71] Incerpi, S., Hsieh, M-T., Lin, H-Y., Cheng, GY., De Vito, P., Fiore, A.M., Ahmed, R.G., Salvia, R., Candelotti, E., Leone, S., Luly, P., Pedersen, J.Z., Davis, F.B., Davis, P.J., 2014. Thyroid hormone inhibition in L6 myoblasts of IGF-I-mediated glucose uptake and proliferation: new roles for integrin $\alpha v \beta 3$. Am. J. Physiol. Cell Physiol. 307, C150-C161.

[72] Iwasaki, A., Gagnon, C., 1992. Formation of reactive oxygen species in spermatozoa of infertile men. Fertility \& Sterility, 47, 409-411.

[73] Krassas, G.E., 2000. Thyroid disease, menstrual function and fertility. Thyroid International, 1, $1-15$.

[74] Krassas, G.E., Papadopoulou, F., Tziomalos, K., Zeginiadou, T., Pontikides, N., 2008. Hypothyroidism has an adverse effect on human spermatogenesis: a prospective, controlled study. Thyroid, 18, 1255-1259.

[75] Krassas, G.E., Perros, P., 2003. Thyroid disease and male reproductive function. J. Endocrinol. Invest. 26, 372-380.

[76] Krassas, G.E., Poppe, K., Glinoer, D., 2010. Thyroid function and human reproductive health. Endocrine Review, 31, 702-705.

[77] Longcope, C., Abend, S., Braverman, L.E., Emerson, C.H., 1990. Androstendione and estrone dynamics in hypothyroid women. Journal of Clinical Endocrinology \& Metabolism, 70, 903-907.

[78] Mancini, A., Festa, R., Silvestrini, A., Nicolotti, N., Di Donna V., La Torre, G., Pontecorvi, A., Meucci, E., 2009. Hormonal regulation of total antioxidant capacity in seminal plasma. Journal of Andrology, 30 (5), 534-540.

[79] Redmond, G.P., 2004. Thyroid dysfunction and women's reproductive health. Thyroid, 14(Suppl. 1), S5-S15.

[80] Rijntjes, E., Gomes, M.L.M., Zupanič, N., Swarts, H.J.M., Keijer, J., Teerds, K.J., 2017. Transient hypothyroidism: Dual effect on adulttype Leydig cell and Sertoli cell development. Front. Physiol. 8, 323.

[81] Ruder, E.H., Hartman, T.J., Blumberg, J., Goldman, M.B., 2008. Oxidative stress and antioxidants: exposure and impact on female fertility. Human Reproduction Update, 14 (4), 345-357.

Page | 18 
[82] Stray-Pedersen, B., Tray-Pedersen, S., 1984.Etiologic factors and subsequent reproductive performances in 195 couples with a prior history of habitual abortion. American Journal of Obstetrics \& Gynecology, 148 (2), 140-146.

[83] Van Herck, S.L.J., Geysens, S., Bald, E., Chwatko, G., Delezie, E., Dianati, E., Ahmed, R.G., Darras, V.M., 2013.Maternal transfer of methimazole and effects on thyroid hormone availability in embryonic tissues. Endocrinol. 218, 105-115.

[84] Wajner, S.M., Wagner, M.S., Maia, A.L., 2009. Clinical implications of altered thyroid status in male testicular function. Arq Bras EndocrinolMetab. 53(8), 976-982.

[85] Wortsman, J., Rosner, W., Dufau, M.L., 1987. Abnormal testicular function in men with primary hypothyroidism. American Journal of Medicine, 82, 207-212.

Citation: Ahmed R.G. Maternal Hypothyroidism and Reproduction. ARC Journal of Animal and Veterinary Sciences. 2018; 4(2):15-19. doi: dx.doi.org/ 10.20431/2455-2518.0402003.

Copyright: (C) 2018 Authors. This is an open-access article distributed under the terms of the Creative Commons Attribution License, which permits unrestricted use, distribution, and reproduction in any medium, provided the original author and source are credited. 